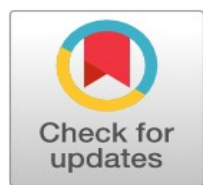

\title{
Knowledge sharing behavior, job attitudes, OCB and organizational learning culture
}

\author{
Yasir Syam Husain ${ }^{1 *}$, Samdin ${ }^{2}$, Nurwati $^{3}$, Husin ${ }^{4}$ \\ 1,2,3 Department of Management Science, Halu Oleo University, Southeast Sulawesi, Kendari, Indonesia \\ ${ }^{4}$ Economic and Business Faculty, Halu Oleo University, Southeast Sulawesi, Kendari, Indonesia
}

\author{
Keywords \\ Knowledge sharing behavior \\ Job attitudes \\ Organizational citizenship \\ Organizational learning culture
}

Received: 28 April 2017

Accepted: 15 June 2017

Published: 21 August 2017

\begin{abstract}
This research tested the moderating effect of Organizational Learning Culture (OLC) with Organizational Citizenship Behavior (OCB) as a mediator variable on relationship of Job Attitudes (JA) and Knowledge Sharing Behavior (KSB). This investigation aims to clarify the linkage between JA, OCB, OLC and KSB. Research design was based on deductive approach and quantitative methods for the purpose of exploratory analysis. 100 respondents were involved in this survey in which 68 facilitators were from Urban Poverty Alleviation Program and 32 others were from Foundation for Development of Rural Potential. Data collected are analyzed and supported by SEM Program. Study showed that JA were not related significantly to KSB. The study also found that JA are correlated positivly and significantly to OCB. OCB has been found as a significant mediator of correlation between JA and KSB. It also found that OLC is a strong significant moderator of OCB toward KSB. It means that OLC has the most of role in strengthening of OCB to mediate JA and KSB. It suggests that in future research may investigate the role of OLC as a moderator variable for JA toward KSB.
\end{abstract}

(C) 2017 The Author(s). Published by TAF Publishing.

\section{INTRODUCTION}

Knowledge sharing behavior is a part of knowledge management (Mohamed, 2014; Idris, Nita \& Godwin, 2015) including the exchange of knowledge, skill, experiences, and capabilities among co-workers or employees. Knowledge sharing behavior is interpreted to supply the information for the task of other people who can help them to negotiate the problems, policies, or development of new ideas (Pulakos, Dorsey \& Borman, 2003; O'Donohue, Sheehan, Hecker \& Holland, 2007).

For a dynamic and competitive economy, knowledge has a crucial role for sustainable competitive advantage (Davenport \& Prusak, 1998). It is considered as a value that makes competitive advantage and remains in the market (Darvish \& Nazari, 2013). The knowledge possessed by the firm is a strategic resource that can create a competitive advantage (Demsetz, 1988; Spender, 1996). Knowledge sharing has a few barriers. They are the lack of time, loss of awareness in knowledge management, and lost consciousness to knowledge (Leistner, 2010). The barriers occurred for the reason created and stored knowledge in organization's members (Chow, 2008; Ali, 2012).

The sticky in transferring knowledge was a key issue in the firm, because the transfer of knowledge within the firm takes time, incurs costs, and uncertainty (Szulanski, 2003). Knowledge sharing behavior was not common because people considered that their knowledge is a valuable asset and had a natural tendency to keep their information Davenport \& Prusak, (as cited by Hsu, Ju, Yen \& Chang, 2007; Teh \& Sun, 2012). . The reluctance of employees to share their

\footnotetext{
${ }^{*}$ Corresponding author: Yasir Syam Husain

${ }^{\dagger}$ Email: yasyam73@gmail.com
} 
knowledge with colleagues has created a problem for organization's survival (Lin, 2007; Teh \& Sun, 2012). Salman (2015) stated that JA are linked with KSB. Teh \& Sun (2012) has found that OCB have a direct effect on KSB but could not act as a mediator.

Most of scholars agreed that JA have correlated indirectly with KSB (Bock \& Kim, 2001; Ryu, Ho \& Hsu, 2003; Lin \& Lee, 2004; Chatzoglou \& Vraimaki, 2009; Tohidinia \& Mosakhani, 2010; Zboralski, 2009). Antecedents of knowledge sharing in communities of practice (Zboralski, 2009; Jeon, Kim \& Koh, 2011; Zhang \& Ng, 2012; Jarvenpaa \& Staples, 2001), but the other scientists concluded that JA linked directly with KSB (Teh \& Sun, 2012). The other results of research show that OLC is correlated with OCB and Knowledge Sharing behavior.

Islam (2012) and Jo \& Joo (2012) in their study found that OLC affected OCB and Knowledge sharing Behavior. It is indicating that the development of OLC will increase the KSB of employees. It also concluded that OLC has a strategic role towards both variables whether OCB or KSB. Al-Zu'bi (2011) stated that the antecedents of knowledge sharing and JA are OCB. This research will investigate the relationship between JA, OCB, OLC and KSB.

\section{LITERATURE REVIEW}

\section{Knowledge Sharing Behavior}

Knowledge sharing is that activity where agents (individuals, communities or organizations) exchange their knowledge (information, skills or expertise) (Ali, 2012; Blau, 1964).

It is linked to the knowledge management process, which can be broadly characterized by four activities, the creation, storage and retrieval, transfer and application of knowledge (Ireson \& Burel, 2010; Ali, 2012; Naqshbandi, Kumar \& Markscheffel, 2017). Davenport \& Prusak (1998) defined that "Knowledge is a fluid mix of framed experiences, values, contextual information, and expert insight that provide a framework for evaluating and incorporating new experiences and information". Knowledge sharing behavior is spread and shares knowledge that has a value possessed by other members in the organization (Ryu et al., 2003). Knowledge sharing was supported by different purposes. They are to acquire knowledge, to reuse knowledge, and to develop new knowledge (Huysman \& Dewit, 2002). According to Lin (2007), knowledge sharing is fundamental to generate new ideas and develop new opportunities through the socialization and learning process of employees. Knowledge sharing plays an essential role in the organizational process because it helps an organization to transfer new ideas or solutions (Islam, 2012).

\section{Job Attitudes}

TRA (Fishbein \& Ajzen, 1977) and TPB (Ajzen, 1991) explained the connection between attitude to behave, subjective norms, and control of perceived behavioral as the independent variables, intention to behave as a mediator variable, and behavior as a dependent variable. These theories stated that behavior will arise when there is an intention in a person to behave that is determined by attitude to behave, subjective norms, and control of perceived behavior. Both theories are applied to predict the influence of factors on KSB. Bock, Zmud, Kim \& Lee (2005) stated that the KSB is determined by the intention to behave and intention to behave is determined by the attitudes to share knowledge. Ryu et al. (2003) argued that TPB as a theory which is considered success in predicting KSB. This finding indicates that JA are related to KSB with intention to share as a mediator. Holotezi (2002) found that JA were not correlating indirectly with $\mathrm{KSB}$. It is consistent with $\mathrm{Al}-\mathrm{Zu}$ 'bi (2011) who found that JA are not an antecedent of KSB, but contrary to Teh \& Sun (2012) who clarify that JA are directly related to KSB. To fill the gap of these findings, researcher assumes that enhancement of JA will spur KSB. Thus, it proposed a hypothesis that:

H1: JA affects positive significantly toward KSB.

The study showed that job satisfaction has a significantly influence on OCB (Huang, You \& Tsai, 2012), and organizational commitment also has a significant influence on OCB in organizations (Ali, 2012; Schappe, 1998; Ali, 2012. However, another study found that job satisfaction (Schappe, 1998; Mohamed, 2014; Huang et al., 2012) and organizational commitment (Ali, 2012; Huang et al., 2012; Teh \& Sun, 2012) have no significant effect on OCB of an individual. Job involvement also showed that it has a significant effect on OCB in organizations (Ali, 2012; Teh \& Sun, 2012; Naqshbandi, Singh \& Ma, 2016). Al-Zu'bi (2011) concluded in their research that job attitude is an antecedent of organizational citizenship behavior. As the determinant variables, JA show the significant effect on OCB (Holotezi, 2002). Furthermore, researcher hypothesized that:

H2: JA affects positive significantly toward organizational citizenship behavior (OCB).

\section{Organizational Citizenship Behavior}

OCB is the determinant of KSB (Al-Zu'bi, 2011; Ramasamy \& Thamaraiselvan, 2011; Teh \& Yong, 2011; Islam, 2012; 
Teh \& Sun, 2012). According to Susanti \& Wimbarti (2012), OCB is not related to tacit KSB (Susanti \& Wimbarti, 2012). OCB is a partial mediator (Islam, Hasan, Ahmed \& Ahmed, 2011; Supriyanto, 2013; Allameh, Zamani \& Davoodi, 2011; Jofreh, Aghaei \& Mamqani, 2014; Naqshbandi \& Kaur, 2011d). However, OCB is not able to mediate correlation between JA and KSB (Teh \& Sun, 2012). Finally, it can be concluded that the improving of OCB would affect the growth of KSB. On the contrary, the lower OCB would produce lower KSB. Furthermore, it proposed the hypotheses that:

H3: OCB affects positive significantly toward KSB.

H4: OCB affects positive significantly toward mediation relationship between JA and KSB.

\section{Organizational Learning Culture}

Behavioral Theory of the Firm (Cyert \& March, 1963, Ali, 2012) stated a firm as an adaptive system, where experiences were embedded in a number of standard operating procedures (routine) in which dispute resolution procedures are based on the mechanism that has been set before. Time to time and with experiences changing, the firm changed its routines through the search process and organizational learning.

The view of this behavior theory was adopted by Huber (1991) and suggested that organizational learning occurred when components of organization acquire knowledge and recognize it as a potential benefit. Learning is one of the organizational culture elements (Schein, 1993; Robbins \& Judge, 2013). OLC is an antecedent of OCB (Somech \& Drach-Zahavy, 2004; Islam et al., 2012). Furthermore, the more the OLC, the higher the OCB of employees. However, Islam et al. in Karimi \& Akbari (2013) showed that there is no significant correlation between organizational learning ability and OCB.

Therefore, an improving of organizational learning ability would not affect growth of OCB. Organizational culture has a linkage with KSB (Holotezi, 2002; Issa \& Haddad, 2008; Kouchaki, Ghayoomi \& Moradi, 2012). As a process of learning, OLC has significantly affected KSB (Islam et al., 2011). Finally, it can be concluded that the improving of OLC will strengthen OCB to improve KSB. Instead, the low OLC will give a weak OCB on the growth of KSB. Furthermore, researcher hypothesized that:

H5: OLC affects positive significantly toward moderation relationship between OCB and KSB.

Thus, conceptual framework can be seen in the following Figure 1.

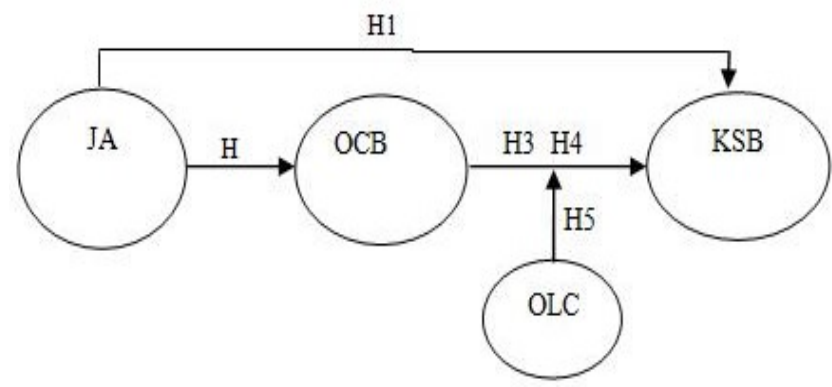

FIGURE 1. Conceptual framework

\section{RESEARCH METHODOLOGY Design}

This research designs a deductive approach with quantitative method to explain the correlation between JA and KSB mediated by OCB and moderated by OLC. All hypotheses developed were tested using Structural Equation Modeling (SEM) processed by AMOS 22.

\section{Samples}

The total samples were 100 facilitators consisting of 68 facilitators of Urban Poverty Alleviation Program, and 38 facilitators of Foundation for Development of Rural Potential in Indonesia. The data were collected during the period of January 2015-November 2015 using a questionnaire and by personally visiting the organizations.

\section{Measures}

Standardized instruments were used for collecting the data. There were three indicators for measuring job attitude developed by Teh \& Sun (2012). They are job involvement which is measured in four items developed by Schappe (1998), job satisfaction which is measured in six items developed by Islam et al. (2011), and organizational commitment which is measured in five items developed by (Lee \& Allen, 2002; Teh \& Sun, 2012). OCB is measured based on five main indicators developed by Organ (1988). They are altruism, civic virtue conscientiousness, and courtesy sportsmanship.

OLC is measured based on seven main indicators developed by (Szulanski, 2003). They are continuous learning, interaction and dialogue, collaborative team, creating a system, empowering people, connecting with organizations, and leadership strategy. Knowledge sharing behavior is measured based on two main indicators namely knowledge donation and knowledge collection (Jansen, Van Den Bosch 
\& Volberda, 2006; Tohidinia \& Mosakhani, 2010; Schermerhorn \& Harris Bond, 1997). Likert scale is used to measure the employees' responese on a 5-point scale from strongly disagree to strongly agree. Construct validity is measured with product moment (pearson) that should be in value minimum of $r \geq 0.3$ (Arikunto, 2006). Reliability test is analyzed with Cronbach's Alpha $>0,6$ (Sekaran, 1992). Using $\alpha=5 \%$, validity and reliability test is processed by SPSS 22 and results show that all constructs are valid and reliable.

\section{RESULTS}

\section{Descriptive Variables}

Descriptive Statistic were used to describe the variables generally. The strength of each indicator should confirm the lambda value in range of $\geq 0.40$ (Ferdinand, 2002).

Referring to Performance Importance Analysis (PIA) Muthusamy, White \& Carr, (2007) show Job satisfaction and organizational commitment as the main factors of job attitudes; civic virtue, conscientiousness, and sportsmanship were the main factors of OCB; collaborative team, creating a system, and empowering people were the main factors of OLC; and knowledge donation and knowledge collection were the main factors of KSB. Descriptive Statistic are presented in Table 1.

TABLE 1. Descriptive variable

\begin{tabular}{llcc}
\hline \hline Constructs & Indicators & Mean & Loading Factor \\
\hline Job Attitudes & Job Involvement & 3.89 & 0.61 \\
& Job Satisfaction & 3.84 & 0.85 \\
& Organizational Commitment & 3.60 & 0.68 \\
Organizational & Altruism & 3.88 & 0.56 \\
Culture Behavior & Civic Virtue & 3.70 & 0.59 \\
& Contentiousness & 3.84 & 0.58 \\
& Courtesy & 4.01 & 0.65 \\
& Sportsmanship & 3.94 & 0.68 \\
Organizational & Continuous Learning & 4.08 & 0.79 \\
Learning Culture & Interaction And Dialogue & 3.85 & 0.55 \\
& Collaborative And Team & 3.82 & 0.70 \\
& Creating A System & 4.07 & 0.80 \\
& Empowering People & 3.83 & 0.81 \\
& Connecting to Organizations & 4.12 & 0.73 \\
Knowledge Sharing & Keadership Strategy & 3.99 & 0.78 \\
Behavior & Knowledge donation & 3.87 & 0.83 \\
\hline \hline
\end{tabular}

\section{Hypotheses Testing}

Result of testing indicated the standardized regression weights as shown in Tabel 2. For the moderation variable, it used Ping and Jöreskog methods, as stated by Rohman, Solimun \& Soehono (2013), to interact OLC with OCB. The test results of SEM can be seen in Table 2 .

TABLE 2 . Standardized regression weights

\begin{tabular}{|c|c|c|c|}
\hline Effect & Variable & $\overline{\text { OCB }}$ & KSB \\
\hline \multirow[t]{2}{*}{ Directly } & $\mathrm{JA}$ & $0.56^{* *}(\mathrm{~s})$ & 0.06 (ns) \\
\hline & ОСВ & & $0.30^{* *}(\mathrm{~s})$ \\
\hline Mediation & ОсВ & & $0.17(\mathrm{~s})$ \\
\hline Moderation & OLC $x$ OCB & & $0.59^{* *}(\mathrm{~s})$ \\
\hline
\end{tabular}

TABLE 3 . Goodness of fit index

\begin{tabular}{llcc}
\hline \hline Criteria & Cutt off & Output & Remarks \\
\hline Chi-square & Expected small & 930.29 & Small \\
GFI & $\geq 0.90$ & 0.28 & Not fit \\
AGFI $^{*} \geq 0.90$ & 0.18 & Not fit & \\
CFI & $\geq 0.95$ & 0.96 & Fit \\
TLI & $\geq 0.95$ & 0.96 & Fit \\
RMSEA & $\leq 0.08$ & 0.04 & Fit \\
\hline \hline
\end{tabular}

Source: Ferdinand (2002)

The model is feasible if at least one method of testing the feasibility of the model is fulfilled because in practice it is very difficult to meet the fifth test feasibility. However, when feasibility test model can meet more than one eligibility criterion, SEM will be better than only one (Widarjono, 2010).

The model as shown in Figure 3, showed that the values of CFI was 0.96, TLI was 0.96, and RMSEA was 0.04. It was stated by Hair, Anderson, Tatham \& Black (1995) that the values of CFI and TLI $\geq 0.95$ and RMSEA $\leq 0.08$ were within the expected range of values that could be accepted. Therefore, it could be accepted even thought the value of Chi-square, GFI and AGFI were not within the expected range. Finally, it could be concluded the hypotheses that were previously are proposed as following:

H1 $: \mathrm{JA} \rightarrow \mathrm{KSB}=$ rejected

H2 : JA $\rightarrow$ OCB $=$ accepted

H3 : OCB $\rightarrow$ KSB $=$ accepted

H4 : $\mathrm{JA} \rightarrow \mathrm{OCB} \rightarrow \mathrm{KSB}=$ accepted

H5 : OCB $\times$ OLC $\rightarrow$ KSB $=$ accepted

\section{DISCUSSION \& CONCLUSION}

Study reveals that JA have correlated insignificantly with KSB. Therefore, Hypothesis (H1) is rejected. It means that the improvement of facilitators' job attitude will not de- 
velop KSB. Job satisfaction and organizational commitment were the crucial elements of job attitudes. This finding is different from Teh \& Sun (2012) who stated that JA are the main point of KSB. It occured because of the different situation of research which previously was in private sector while this research was in NGO. It is implying that employes who work in NGO such as in Urban Poverty Alleviation Program and Foundation for Development of Rural Potential will appear knowledge sharing if they are satisfied and committed to the organization. In addition, Teh \& Sun (2012) imply that job involvement is the component to understand the task so that they are more confident and willing to engage in KSB.

In fact, facilitators in two NGOs do not have KSB because they have an opportunity to apply their abilities or skills that make them worry for lost power or position within organization which is stated by Chow (2008) that most of the employees are not ready to share their knowledge that gives a worth value because of worrying for exchanging their position held today.

Therefore, it is concluded that employees in private sector are more KSB than in public sector such as in NGO. This finding has been confirmed by research such as (Zhang \& $\mathrm{Ng}$, 2012). Study reveals that JA have a positively significant effect on OCB. Therefore, hypothesis (H2) is accepted. It means that the improvement of facilitators' job attitude will develop OCB. This finding is going on Teh \& Sun (2012) who stated that JA have a direct effect on OCB because employees have job involvement and job satisfaction.

Organ (1988) stated that job involvement and job satisfaction are correlated with OCB. In addition, Schappe (1998) stated that organizational commitment affects OCB. It can be concluded that employees who work both in private sector and public sector will act according to OCB when they have a satisfaction, commitment, and involvement related to job organization. The study found that OCB impacts positively significantly the KSB. Therefore, Hypothesis (H3) is accepted. Sportsmanship becomes the biggest element for facilitator to behave with knowledge sharing with colleagues.

This finding is consistent with Teh \& Sun (2012) research who stated that OCB is the determinant of KSB. It is supported by various studies such as Al-Zu'bi (2011); Ramasamy \& Thamaraiselvan (2011). This study also found that OCB impacts positively significantly the mediating of the relationships between JA and KSB (Albarracin, Johnson \& Zanna, 2014). Therefore, Hypothesis (H4) is accepted. It means that the improvement in OCB will not mediate the correlation with KSB. This finding is contrary to Teh \& Sun (2012) finding OCB could not mediate the correlation between these variables. They explain that private sector in Malaysia has oriented in collectivism so that OCB has manifested in organization to KSB. The other factor contributing to IS personnel of private sector is altruism that gives an effect on KSB (Teh \& Sun, 2012) while in this research not only altruism but also all of the indicators of OCB developed by Organ (1988) are affecting KSB. It is supported by (Al-Zu'bi, 2011; Ramasamy \& Thamaraiselvan, 2011)). Study showed that OLC affects significantly in moderating the correlation between OCB and KSB.

Therefore, hypothesis (H5) is accepted. It means that the improvement of OLC will strengthen the correlation between organizational citizenship behaviors and KSB. It may conclude that OLC has a strategic role to strengthen OCB toward KSB (Casimir, Lee \& Loon, 2012). Creating a system, collaborative and team, and Empowering people are the main reason for OLC. This study is going on Teh \& Sun (2012) who revealed it is a moderator variable for OCB. This study is supported by Somech \& Drach-Zahavy (2004) who stated that OLC is the component of OCB, and Islam et al. (2012) stated that OLC is linked with KSB. We concluded that JA have not affected KSB but affected OCB, OCB also acted as a mediating variable toward KSB, and OLC is full moderating for OCB toward KSB (Ho, Hsu \& Oh, 2009). Thus, we proposed "Organizational Learning Model (OLM)" that presented is in Figure 2.

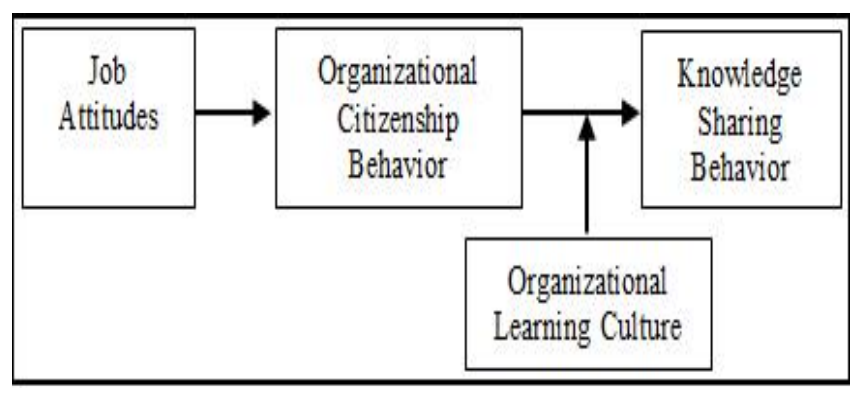

FIGURE 2 . Organizational Learning Model (OLM)

\section{Implications}

This study gives an implication for developing of managerial and theoretical aspects. Form managerial perspective, JA should be concerned in NGOs. OCB has a capital role to mediate the JA determined by civic virtue, conscientiousness, and sportsmanship. These three variables were the main factors of OCB that should be owned by facilitator within facilitating the needs of community. OLC has a strategic role 
to moderate OCB on KSB which determines factors that were collaborative team creating a system, and empowering people. These three indicators imply that the facilitators should establish a collaborative team, create a system, and empowering people to facilitate the community interests. With knowledge sharing behaviors' facilitator is collecting knowledge from the other people and donating his knowledge to the community. Theoretical Implications had given contributions to developing model of KSB resulted from organizational learning model as a new model which emphasizes KSB as an element important for NGOs and OLC as a moderator variable.

\section{Limitations and Future Research}

OLC acted as a moderator variable for OCB, while it had another moderation that is unreachable from this study such as job attitude which is found by (Malik \& Danish, 2010). Thus, future research may investigate the other role of OLC. Subjective norm and perceived behavior of control are the other components of KSB that are unreachable in this research. So in the future research may add these variables. Samples of this study are facilitators who work in NGO so that in future research may investigate in another profession such as in government or private sector.

\section{REFERENCES}

Ajzen, I. 1991. The theory of planned behavior. Organizational Behavior \& Human Decision Processes, 50(2): 179-211.

DOI: 10.1016/0749-5978(91)90020-T

Albarracin, D., Johnson, B.T., \& Zanna, M.P. 2014. The handbook of attitudes. New Jersy, NJ: Lawrence Erlbaum Associates Publishers Mahwah.

Ali, M.R.M. 2012. Determinants of knowledge sharing in professional services case study: The network operations di- rectorate in Jawwal Company. Unpublished doctoral dissertation, Islamic University of Gaza, Gaza, PS.

Allameh, M., Zamani, M., \& Davoodi, S.M.R. 2011. The relationship between organizational culture and knowledge managea case study: Isfahan university. Procedia Computer Science, 3: 1224-1236. DOI: 10.1016/j.procs.2010.12.197

Al-Zu'bi, H.A. 2011. Organizational citizenship behavior and impacts on knowledge sharing: An empirical study. Interna-

Business Research, 4(3): 221-225. DOI: 10.5539/ibr.v4n3p221

Arikunto, S. 2006. Prosedur penelitian suatu pendekatan praktik. Jakarta, ID: Rineka Cipta.

Arif, K.B. 2013. Multidimensional scaling (MDS). URL: goo.gl/xhsAMy.

Blau, P.M. 1964. Exchange and power in social life. New York, NY: Wiley Online.

Bock, G.W., \& Kim, Y.G. 2001. Breaking the myths of rewards: An exploratory study of attitudes about knowledge sharing. Information Resources Management Journal, 15(2): 14-22.

Bock, G.W., Zmud, R.W., Kim, Y.G., \& Lee, J.N. 2005. Behavioral intention formation in knowledge sharing: Examining the roles of extrinsic motivators, social-psychological forces, and organizational climate. MIS Quarterly, 29(1): 87-111. DOI: $10.4018 /$ irmj.2002040102

Casimir, G., Lee, K., \& Loon, M. 2012. Knowledge sharing: Influences of trust, commitment and cost. Journal of Knowledge Management, 16(5): 740-753. DOI: 10.1108/13673271211262781

Chatzoglou, P.D., \& Vraimaki, E. 2009. Knowledge-sharing behaviour of bank employees in Greece. Business Process Man- agement Journal, 15(2): 245-266. DOI: 10.1108/14637150910949470

Chow, L.S. 2008. Social network, social trust and shared goals in organizational knowledge sharing. Information \& Manment, 45(7): 458-465. D0I: 10.1016/j.im.2008.06.007

Cyert, R.M., \& March, J.G. 1963. A behavioral theory of the firm. Englewood Cliffs, NJ: Prentice-Hall.

Darvish, H., \& Nazari, E.A. 2013. Organizational learning culture the missing link between innovative culture and innova- tions (Case study: Saderat Bank of Iran). Economic Insights-Trends \& Challenges, 65(1): 23-34.

Davenport, T.H., \& Prusak, L. 1998. Working knowledge: How organizations manage what they know. Boston, MA: Har- vard Business Press.

Demsetz, H. 1988. The theory of the firm revisited. Journal of Law Economics \& Organization, 4(1): 141-161.

Ferdinand, A. 2002. Structural equation modeling dalam penelitian manajemen. Semarang, ID: Badan Penerbit Univer- sitas Diponegoro. 
Fishbein, M., \& Ajzen, I. 1977. Belief, attitude, intention, and behavior: An introduction to theory and research. Reading, MA: Addison-Wesley Publishing Company.

Hair, J.F. Jr., Anderson, R.E, Tatham, R.L., \& Black, W.C. 1995. Multivariate data analysis. New Jersey, NJ: Prentice Hall International Editions.

Ho, C.T.B., Hsu, S.F., \& Oh, K.B. 2009. Knowledge sharing: Game and reasoned action perspectives. Industrial Management \& Data Systems, 109(9): 1211-1230. DOI: 10.1108/02635570911002289

Holotezi, A. 2002. The relationship between knowledge management and organizational culture. Applied Information Management \& the Gradute School: Journal University of Orergon, 3(2): 15-22.

Hsu, M.H., Ju, T.L., Yen, C.H., \& Chang, C.M. 2007. Knowledge sharing behavior in virtual communities: The relationship be tween trust, self-efficacy, and outcome expectations. International Journal of Human-Computer Studies, 65(2): 153DOI: $10.1016 /$ j.ijhcs.2006.09.003

Huang, C.C., You, C.S., \& Tsai, M.T. 2012. A multidimensional analysis of ethical climate, job satisfaction, organizational com- mitment, and organizational citizenship behaviors. Nursing Ethics, 19(4): 513-529. DOI: 10.1177/0969733011433923 Huber, G.P. 1991. Organizational learning: The contributing processes and the literatures. Organization Science, 2(1): 88- 115. DOI: $10.1287 /$ orsc.2.1.88

Huysman, M.H., \& Dewit, D.H. 2002. Knowledge sharing in practice. Dordrecht, NL: Springer Science \& Business Media. Idris, K.M., Nita, A.K., \& Godwin, A.U. 2015. Impact of organizational culture on knowledge management process in construcAsian Social Science, 11(9): 281-290. DOI: /10.5539/ass.v11n9p281

Ireson, N., \& Burel, G. 2010. Knowledge sharing in e-collaboration. Electronic Government, 4(5): 351-362.

DOI: $10.1007 / 978-3-642-14799-9 \_30$

Islam, T., Anwar, F., Khan, S.U.R., Rasli, A., Ahmad, U.N.B.U., \& Ahmed, I. 2012. Investigating the mediating role of org- $\quad$ anizational citizenship behavior between organizational learning culture and knowledge sharing. World Applied Sci- ences Journal, 19 (6): 795-799.

Islam, Z.M. 2012. The mediating effects of socialization on organizational contexts and knowledge sharing. Journal Knowl- edge Global, 3(1): 31-48.

Islam, Z.M., Hasan, I., Ahmed, S.U., \& Ahmed, S.M. 2011. Organizational culture and knowledge sharing: Empirical evidence from service organizations. African Journal of Business Management, 5(14): 5900-5909.

Issa, R.R., \& Haddad, J. 2008. Perceptions of the impacts of organizational culture and information technology on knowledge sharing in construction. Construction Innovation, 8(3): 182-201. DOI: 10.1108/14714170810888958

Jansen, J.J., Van Den Bosch, F.A., \& Volberda, H.W. 2006. Exploratory innovation, exploitative innovation, and performance: Effects of organizational antecedents and environmental moderators. Management Science, 52(11): 1661-1674.

DOI: $10.1287 / \mathrm{mnsc} .1060 .0576$

Jarvenpaa, S.L., \& Staples, D.S. 2001. Exploring perceptions of organizational ownership of information and expertise. Jourof Management Information Systems, 18(1): 151-183. DOI: 10.1080/07421222.2001.11045673

Jeon, S., Kim, Y.G., \& Koh, J. 2011. An integrative model for knowledge sharing in communities-of-practice. Journal of Knowl- edge Management, 15(2): 251-269. D0I: 10.1108/13673271111119682

Jo, S.J., \& Joo, B.K. 2011. Knowledge sharing: The influences of learning organization culture, organizational commitment, and organizational citizenship behaviors. Journal of Leadership \& Organizational Studies, 18(3): 353-364. DOI: $10.1177 / 1548051811405208$

Jofreh, M., Aghaei, T., \& Mamqani, N.B. 2014. Investigating the impact of job attitudes on organizational citizenship behavior and knowledge sharing. Journal of Educational and Management Studies, 4(1): 01-05.

Karimi, F., \& Akbari, M. 2013. Predicting organizational citizenship behavior on the basis of organizational learning capabilMiddle-East Journal of Scientific Research, 18(9): 1371-1379.

Kouchaki, M., Ghayoomi, A., \& Moradi, N. 2012. Studying the relationship between organizational culture (Queen's Model) and feasibility of establishment of a knowledge management system in Iranian gas transmission company. Journal of Occupational Organizational Consulting, 13(12): 101-121.

Lee, K., \& Allen, N.J. 2002. Organizational citizenship behavior and workplace deviance: The role of affect and cognitions. Journal of Applied Psychology, 87(1): 131-140. DOI: 10.1037/0021-9010.87.1.131 
Leistner, F. 2010. Mastering organizational knowledge flow: How to make knowledge work. Hoboken, NJ: John Wiley \& Sons Inc.

Lin, C.P. 2007. To share or not to share: Modeling knowledge sharing using exchange ideology as a moderator. Personnel Review, 36(3): 457-475. DOI: 10.1108/00483480710731374

Lin, H.F., \& Lee, G.G. 2004. Perceptions of senior managers toward knowledge-sharing behaviour. Management Decision, 42(1): 108-125. DOI: 10.1108/00251740410510181

Malik, M.E., \& Danish, R.Q. 2010. Impact of motivation to learn and job attitudes on organizational learning culture in a public service organization of Pakistan. South Asian Studies, 25(2): 217-223.

Mohamed, 0. 2014. Knowledge sharing initiatives in local authorities in Malaysia. Unpublished doctoral dissertation,

School of the Built Environment University of Salford Greater, Manchester, UK.

Muthusamy, S.K., White, M.A., \& Carr, A. 2007. An empirical examination of the role of social exchanges in alliance perfor- mance. Journal of Managerial Issues, 19(1): 53-76.

Naqshbandi, M.M., Kumar, S., \& Markscheffel, B. 2017. The evolving knowledge landscape ofopen innovation research- International networks and keywords analysis. Paper presented at the 18th Collnet Meeting, Canterbury, UK, 2017.

Naqshbandi, M.M., Singh, S.K.G., \& Ma, P. 2016. The link between organisational citizenship behaviours and open innovation:

A case of Malaysian high-tech sector. IIMB Management Review, 28(4): 200-211.

Naqshbandi, M.M., \& Kaur, S. 2011d. A study of organizational citizenship behaviours, organizational structures and open innovation. International Journal of Business \& Social Science, 2(6): 182-193.

O'Donohue, W., Sheehan, C., Hecker, R., \& Holland, P. 2007. The psychological contract of knowledge workers. Journal of Knowledge Management, 11(2): 73-82. DOI: 10.1108/13673270710738924

Organ, D.W. 1988. Organizational citizenship behavior: The good soldier syndrome. Lexington, MA: Lexington Books/DC Heath and Com.

Pulakos, E.D., Dorsey, D.W., \& Borman, W.C. 2003. Hiring for knowledge-based competition. In S.E. Jackson, M.A. Hitt, \& A.S. De Nisi (Eds.), Managing knowledge for sustained competitive advantage: Designing strategies for effective human resource management, San Francisco, CA: Jossey Bass

Ramasamy, M., \& Thamaraiselvan, N. 2011. Knowledge sharing and organizational citizenship behavior. Knowledge \& Pro- $\quad$ cess Management, 18(4): 278-284. D0I: 10.1002/kpm.385

Robbins, S.P., \& Judge, T.A. 2013. Organizational behavior. New Jersy, NJ: Pearson Education Inc.

Rohman, M.Z., Solimun, S., \& Soehono, L.A. 2013. Identifikasi variabel moderasi pada pemodelan struktural dengan pen- dekatan interaksi indikator tunggal. Jurnal Mahasiswa Statistik, 1(5): 321-232.

Ryu, S., Ho, S.H., \& Hsu, I. 2003. Knowledge sharing behavior of physicians in hospitals. Expert Systems with Applications, 25(1): 113-122. DOI: 10.1016/S0957-4174(03)00011-3

Salman, I. 2015. Employees' perceeption of human resource management practices and knowledge sharing behavior. Unpublished doctoral dissertation, Massey University, Palmerston North, NZ.

Schappe, S.P. 1998. The influence of job satisfaction, organizational commitment, and fairness perceptions on organizational citizenship behavior. The Journal of Psychology, 132(3): 277-290. DOI: 10.1080/00223989809599167

Schein, E.H. 1993. Organizational culture and leadership. San Francisco, CA: Jossey Bass.

Schermerhorn, J.R., \& Harris Bond, M. 1997. Cross-cultural leadership dynamics in collectivism and high power distance settings. Leadership \& Organization Development Journal, 18(4): 187-193. DOI: 10.1108/01437739710182287

Sekaran, U. 1992. Research methods for business: A skill building approach. New York, NY: John Wiley.

Shahhosseini, S., \& Nadi, M.A. 2015. Analyzing the relationship of organizational trust and organizational culture with knowl- edge sharing behavior in teachers of second intermediate period. Educational Research \& Reviews, 10(6): 722-727.

DOI: 10.5897 /ERR2015.2125

Somech, A., \& Drach-Zahavy, A. 2004. Exploring organizational citizenship behaviour from an organizational perspective:

The relationship between organizational learning and organizational citizenship behaviour. Journal of Occupational \&

Organizational Psychology, 77(3): 281-298. DOI: 10.1348/0963179041752709

Spender, J.C. 1996. Making knowledge the basis of a dynamic theory of the firm. Strategic Management Journal, 17(S2):

45-62. DOI: $10.1002 / \mathrm{smj} .4250171106$ 
Supriyanto, A.S. 2013. Role of procedural justice, organizational commitment and job satisfaction on job performance: The mediating effects of organizational citizenship behavior. International Journal of Business \& Management, 8(15):

57- 62. DOI: $10.5539 /$ ijbm.v8n15p57

Susanti, R., \&Wimbarti, S. 2012. Pengaruh Organizational Citizenship Behavior (OCB) dan persepsi atas dukungan organ- $\quad$ isasi terhadap knowledge sharing dan jenis kelamin sebagai moderator pada karyawan PT. Telekomunikasi indonesia Tbk, kandatel Yogyakarta. Jurnal Psikologi, 8(1): 49-61.

Szulanski, G. 2003. Sticky knowledge. Barriers to knowing in the firm. Sans Fransco, CA: Sage Publication.

Teh, P.L., \& Sun, H. 2012. Knowledge sharing, job attitudes and organisational citizenship behaviour. Industrial Manage- ment \& Data Systems, 112(1): 64-82. DOI: 10.1108/02635571211193644

Teh, P.L., \& Yong, C.C. 2011. Knowledge sharing in is personnel: Organizational behavior's perspective. Journal of Computer Information Systems, 51(4): 11-21.

Tohidinia, Z., \& Mosakhani, M. 2010. Knowledge sharing behaviour and its predictors. Industrial Management \& Data Systems, 110(4): 611-631. DOI: 10.1108/02635571011039052

Widarjono, A. 2010. Analisis statistika multivariat terapan. Yogyakarta, ID: Upp Stim Ykpn.

Zboralski, K. 2009. Antecedents of knowledge sharing in communities of practice. Journal of Knowledge Management, 13(3): 90-101. DOI: 10.1108/13673270910962897

Zhang, P., \& Ng, F.F. 2012. Attitude toward knowledge sharing in construction teams. Industrial Management \& Data Sys- $\quad$ tems, 112(9): 1326-1347. DOI: 10.1108/02635571211278956

— This article does not have any appendix. - 